\title{
KONSTRUKSI PUNGUTAN LIAR PADA PENYELENGGARA PENDIDIKAN DASAR
}

\author{
Dedi Mulyadi $^{1}$ \\ Abahpoli@gmail.com
}

\begin{abstract}
ABSTRAK
Bantuan Oprasional Sekolah (BOS) merupakan program Pemerintah untuk menyukseskan pendidikan wajib belajar 9 tahun, yang dibiayai oleh Program Konpensasi Pengurangan Subsidi Bahan Bakar Minyak (PKPSBBM), namun meskipun adanya Bantuan Oprasional Sekolah (BOS). Implementasi pelaksanaan penyelenggaraan pendidikan seperti sekarang ini, tidak akan terlepas dari permasalahan yang muncul, yang salah satunya permasalahan tentang pungutan liar

Metode penelitian yang digunakan adalah penelitian hukum normatif yang bersifat deskriptif analisis, pengumpulan data dilakukan dengan menggunakan data primer dan data sekunder berupa bahan hukum primer, sekunder dan tertier sebagai data utama. Setelah data sekunder dan primer terkumpul, kemudian diadakan analisis secara kualitatif

Berdasarkan hasil analisis data, disimpulkan bahwa konstruksi pungutan pendidikan pada dasarnya dibuat kepala sekolah dan komite sekolah. Pungutan liar pada penyelenggara pendidikan dasar dengan berbagai modus operandinya sudah menjadi rahasia umum bagi masyarakat dan hal ini sulit dicegah karena melibatkan stakeholders pada lembaga tersebut. Padahal Pungutan liar bertentangan dengan Pasal 9 ayat (1) Peraturan Menteri Pendidikan Dan Kebudayaan No 44 tahun 2012 tentang Pungutan Dan Sumbangan Biaya Pendidikan Pada Satuan Dasar dan Terjadinya pungutan liar tentu ada penyebabnya, faktor penyebab pungli secara umum dapat diklasifikasikan menjadi dua macam, yaitu faktor internal dan faktor eksternal.
\end{abstract}

Kata Kunci: Konstruksi, Pungutan Liar, Penyelenggara Pendidikan

\footnotetext{
${ }^{1}$ Guru SMPN 2 Panyingkiran Majalengka.
} 


\section{A. Latar Belakang}

Indonesia adalah negara hukum dan dalam kehidupan masyarakat nya pun, tidak terlepas dari aturan-aturan yang berlaku, baik aturan yang tertulis maupun aturan yang tidak tertulis, yang meliputi segala bidang kehidupan manusia termasuk di bidang pendidikan. Peraturan-peraturan tersebut harus ditaati sepenuhnya oleh warga negara. Peraturan tersebut ada, dengan tujuan untuk terciptanya kemakmuran dan keadilan dalam lingkungan masyarakat. Apabila peraturan-peraturan tersebut dilanggar, maka akan mendapatkan sanksi yang tegas bagi yang melanggarnya.

Sejalan dengan arah kebijakan pemerintah, program pembangunan pendidikan perlu di tetapkan sebagai elemen sentral pengembangan sumber daya manusia. Peningkatan mutu pendidikan merupakan langkah strategis dalam pengembangan sumber daya manusia. Maka, pemerintah berkewajiban untuk menyediakan pendidikan gratis dan bermutu kepada setiap warga negara sebagaiamana di sebutkan dalam Pasal 31 ayat (1) dan (2) UUD 1945 yang menyatakan bahwa:

(1). Setiap warga Negara berhak mendapatkan pendidikan.

(2). Setiap warga Negara wajib mengikuti pendidikan dasar dan pemerintah wajib membiayainya.

Amanat konstitusi ini di perkuat dengan Pasal 34 ayat (2) dan (3) UndangUndang Republik Indonesia Nomor 20 tahun 2003 tentang sistem pendidikan nasional yang menyatakan bahwa:

(2). Pemerintah dan pemerintah daerah menjamin terselenggaranya wajib belajar minimal pada jenjang pendidikan dasar tanpa memungut biaya.

(3). Wajib belajar merupakan tanggung jawab Negara yang di selenggarakan oleh lembaga pendidikan Pemerintah, Pemerintah Daerah, dan masyarakat.

Kebutuhan akan tenaga pendidikan harus tercukupi dan kualitas tenaga pendidik perlu terus di tingkatkan baik dari segi kompetensi,kualitas sikapmental dan etika profesi. Tenaga pendidikan merupakan suatu konstruksi dalam dunia pendidikan guna menghasilkan pendidikan bermutu dan yang mencerdaskan, terlebih dalam krisis kekinian yang menyangkut pengetahuan dan pendidikan. Konstruksi merupakan bagian pokok dalam sebuah bangunan yang menjadi landasan utama bagi bagian-bagian yang lain. Kokohnya bangunan tersebut sangat dipengaruhi oleh konstruksinya. Dapat dianalogikan, sebuah bangunan pendidikan membutuhkan konstruksi yang kokoh untuk menjaga kekuatan pendidikan tersebut, namun pada saat ini, pendidikan di Indonesia sangat memprihatinkan, hal ini di sebabkan karena faktor ekonomi yang di alami oleh banyak rakyat yang kurang mampu, sehingga pemerintah membuat program wajib belajar 9 tahun guna menyukseskan pendidikan di negeri ini dan salah satu programnya, yakni adanya Bantuan Oprasional Sekolah (BOS) yang dibiayai oleh Program Konpensasi Pengurangan Subsidi 
Bahan Bakar Minyak (PKPSBBM).2 Akan tetapi meskipun adanya Bantuan Oprasional Sekolah (BOS). Implementasi pelaksanaan penyelenggaraan pendidikan di zaman modern, seperti sekarang ini tidak akan terlepas dari permasalahan yang muncul, yang salah satunya permasalahan tentang mahalnya biaya pendidikan. Hal ini tentunya menjadi beban bagi sebagian orang tua murid yang ingin memberikan pendidikan terbaik bagi putraputerinya. Disamping itu, orang tua murid banyak yang mengeluh karena terdapat sekolah yang membebankan murid dengan biaya-biaya diluar perkiraan yang biasa disebut dengan pungutan liar.

Istilah pungutan liar dewasa ini mendapatkan sorotan tajam di tengahtengah masyarakat. Tindakan pungutan liar merupakan suatu pelanggaran yang tidak sesuai dengan norma hukum dan dapat dikategorikan ke dalam tindak pidana korupsi. Korupsi merupakan suatu penyakit yang harus mendapatkan perlawanan secara masif atau bersama-sama. Kejahatan korupsi yang dikenal dengan kejahatan luar biasa (extraordinary crime) tersebut telah banyak merusak sistem tatanan kehidupan baik sosial, ekonomi, politik. Kejahatan yang dilakukan secara berjamaah ini terungkap tidak hanya dilakukan di lingkungan politik semata, akan tetapi telah merasuki sistem pendidikan di negeri ini.

Bertitik tolak dari paparan di atas, pungutan dan sumbangan biaya pendidikan pada satuan pendidikan dasar tertuang dalam Pasal 11 Peraturan Menteri Pendidikan dan Kebudayaan Republik Indonesia Nomor 44 Tahun 2012 tentang Pungutan Dan Sumbangan Biaya Pendidikan Pada Satuan Pendidikan Dasar yang menyatakan bahwa Pungutan tidak boleh:

a. dilakukan kepada peserta didik atau orang tua/walinya yang tidak mampu secara ekonomis;

b. dikaitkan dengan persyaratan akademik untuk penerimaan peserta didik, penilaian hasil belajar peserta didik, dan/atau kelulusan peserta didik dari satuan pendidikan; dan/atau

c. digunakan untuk kesejahteraan anggota komite sekolah atau lembaga representasi pemangku kepentingan satuan pendidikan baik langsung maupun tidak langsung.

Pemerintah telah berupaya mengatasi permasalahan pendidikan dengan memberikan dana Bantuan Operasional Sekolah (BOS), bantuan ini dimaksudkan untuk meringankan beban biaya sekolah terutama bagi masyarakat kurang mampu dan tentunya untuk mencegah terjadinya pungutan liar yang dilakukan oleh oknum kepala sekolah dan guru. Menurut Wakil Ketua KPK M. Jasin mengungkapkan bahwa: ${ }^{3}$

Praktik pungutan liar yang dilakukan oleh oknum kepala sekolah dan guru

2 Saiful anam, Pena Pendidikan, PT. Reka Gagas cipta, Jakarta, 2006, hlm. 2

${ }^{3}$ Erna Eprilianti, 2013 Pelaksanaan Pengawasan DPRD Terhadap Kebijakan Perda No. 20 Tahun 2002 Tentang Penyelenggaraan Pendidikan (Studi Deskriptif Pada DPRD Kota Bandung Mengenai Pelanggaran Pungutan Liar di sekolah) http:// repository. upi.edu/2639/4/S_PKN_0906241_Chapter1.pdf, diakses pada tanggal 30/10/2020 
termasuk bagian dari tindak pidana korupsi. Pasalnya, setiap sekolah, terutama yang berstatus negeri, sudah mendapatkan dana BOS (Dana Bantuan Operasional) sekolah untuk kegiatan belajar dan mengajar.Sehingga, jika ada praktik pungutan liar dengan alasan untuk kegiatan operasional sekolah yang tidak dicukupi oleh dana BOS, besar kemungkinan si oknum yang melakukan pungutan liar, telah menyelewengkan dana BOS itu sendiri. Oknum kepala sekolah dan guru yang melakukan pungutan liar diduga menyelewengkan dana BOS. berdasarkan aturan Pasal 12 c Undang-Undang nomor 31 tahun 1999 sebagaimana telah diubah dengan Undang-Undang Nomor 20 tahun 2001 tentang Pemberantasan Tindak Pidana Korupsi (Tipikor), perbuatan pungutan liar yang dilakukan oknum kepala sekolah dan guru, dapat dikategorikan sebagai gratifikasi.

Berdasarkan penjelasan di atas jelas bahwa jika terjadi pelanggaran pungutan liar yang dilakukan oleh oknum kepala sekolah dan guru terhadap siswa, maka sanksi yang dikenakan cukup berat mengingat tindakan tersebut mengindikasikan tindak pidana korupsi dan dikategorikan sebagai gratifikasi. Hal ini pun dipertegas pula dalam Pasal 10 ayat (1) dan (2) Peraturan Menteri Pendidikan dan Kebudayaan Nomor 75 Tahun 2016 tentang Komite Sekolah yang menyatakan bahwa:

(1). Komite Sekolah melakukan penggalangan dana dan sumber daya pendidikan lainnya untuk melaksanakan fungsinya dalam memberikan dukungan tenaga, sarana dan prasarana, serta pengawasan pendidikan.

(2). Penggalangan dana dan sumber daya pendidikan lainnya sebagaimana dimaksud pada ayat (1) berbentuk bantuan dan/atau sumbangan, bukan pungutan.

Mencermati fenomena di atas, sebagai bentuk keprihatinan atas kurangnya pengawasan dan kinerja lembaga pendidikan yang telah sampai pada titik keputusasaan, maka saya tertarik untuk mengangkat permasalahan tersebut dalam sebuah penelitian jurnal dengan judul "KONSTRUKSI PUNGUTAN LIAR PADA PENYELENGGARA PENDIDIKAN DASAR"

\section{B. Identifikasi Masalah}

Berdasarkan uraian di atas, pokok permasalahan yang akan dibahas dalam jurnal ini adalah sebagai berikut:

1. Bagaimanakah kewenangan penyelenggara pendidikan menarik pungutan atas dasar kesepakatan dengan orangtua/wali siswa

2. Faktor-faktor apa yang menjadi penyebab terjadinya Pungutan Liar di Sekolah Menengah Pertama?

\section{Tujuan Penelitian}


Sesuai dengan permasalahan di atas, maka tujuan penelitian ini adalah:

1. Untuk mengetahui dan menganalisis kewenangan penyelenggara pendidikan menarik pungutan atas dasar kesepakatan dengan orangtua/wali siswa

2. Untuk mengetahui dan menganalisis faktor yang menjadi penyebab terjadinya Pungutan Liar di Sekolah Menengah Pertama

\section{Kerangka Pemikiran}

Kerangka berpikir merupakan model konseptual tentang bagaimana teori berhubungan dengan beragam faktor yang telah diidentifikasi sebagai hal yang penting, dengan demikian dapat dikatakan bahwa kerangka berpikir ialah sebuah pemahaman yang melandasi pemahaman-pemahaman yang lainnya, sebuah pemahaman yang paling mendasar dan menjadi pondasi bagi setiap pemikiran atau suatu bentuk proses dari keseluruhan dari penelitian yang akan dilakukan. ${ }^{4}$ Secara sederhana kerangka berpikir merupakan sintesis tentang hubungan antar variabel yang disusun dari berbagai teori yang telah dideskripsikan.

Kerangka teori dalam penelitian hukum sangat diperlukan untuk membuat jelas nilai-nilai oleh postulat-postulat hukum sampai kepada landasan filosofisnya yang tertinggi. ${ }^{5}$ Teori hukum sendiri boleh disebut sebagai kelanjutan dari mempelajari hukum positif, setidak-tidaknya dalam urutan yang demikian itulah kita merekonstruksikan kehadiran teori hukum secara jelas. ${ }^{6}$ Sebagai kerangka teori yang akan dibahas dalam tulisan ini salah satunya mengenai teori negara hukum.

Indonesia adalah Negara yang berdasar atas hukum sebagaimana tercermin dalam Undang-Undang Dasar 1945. Dalam negara hukum, kekuasaan negara dilaksanakan menurut prinsip dasar keadilan sehingga terikat secara konstitusional pada konstitusi. Hukum menjadi batas, penentu, dasar cara dan tindakan pemerintah serta segala Instansi dalam mencampuri hak dan kebebasan warga negara. Atas dasar hukum pula negara hukum menyelenggarakan apa yang menjadi tujuan negara. Jadi tidak masuk akal jika negara hukum diwujudkan dengan cara yang melawan hukum. ${ }^{7}$ dan pembukaan Undang-Undang Dasar Negara Republik Indonesia tahun 1945, menyebutkan pula bahwa Negara melindungi segenap bangsa Indonesia dan seluruh tumpah darah Indonesia dan untuk memajukan kesejahteraan umum, mencerdaskan kehidupan bangsa, dan ikut melaksanakan ketertiban dunia yang berdasarkan, perdamaian abadi dan keadilan sosial. Kalimat tersebut menjelaskan terdapat kewajiban bagi negara tentang bagaimana caranya mengusahakan agar semua rakyat dapat mengenyam pendidikan dan memerlukan suatu dasar pengaturan dalam bentuk peraturan perundang -

\footnotetext{
${ }^{4}$ Rina Hayati, Pengertian Kerangka Berpikir, Jenis, Ciri, dan Cara Menuliskannya, https://penelitianilmiah.com/kerangka-berpikir/\#: :text= Kerangka\%20berpikir\% 20adalah $\% 20$ penjelasan $\% 20$ sementara, $\operatorname{argumentasi} \% 20 \mathrm{kita} \% 20$ dalam $\% 20$ merumuskan $\% \quad 20$ hipotesis. diakses pada tanggal 30/10/2020

${ }^{5}$ Satjipto Rahardjo, llmu Hukum, P.T. Citra Aditya Bakti, Bandung, 1991, hlm. 254.

${ }^{6}$ Ibid, hlm. 253

${ }^{7}$ Budiyanto, Dasar-Dasar Ilmu Tata Negara, Erlangga, Jakarta, 2000, hlm 55.
} 
undangan atau konstitusi. Dalam UUD 1945 juga mengamanatkan Pemerintah harus mengusahakan dan menyelenggarakan suatu sistem pendidikan nasional yang meningkatkan keimanan kepada Tuhan Yang Maha Esa, serta akhlak mulia dalam rangka mencerdaskan bangsa. Sistem pendidikan nasional harus mampu menjamin pemerataan kesempatan pendidikan, peningkatan mutu menejemen pendidikan untuk menghadapi tantangan perkembangan dan kemajuan ilmu pengetahuan dan teknologi. Sehingga perlu melakukan perubahan dan pembaharuan pendidikan secara terencana, terarah dan berkesinambungan.

Dengan demikian, sesuai perkembangan waktu dan pendidikan, UndangUndang Nomor 2 Tahun 1989 tentang Sistem Pendidikan Nasional diganti dan disempurnakan dengan Undang-Undang Nomor 20 Tahun 2003 tentang sistem Pendidikan Nasional dan Undang-Undang Nomor 14 Tahun 2005 tentang Guru dan Dosen. Pada Pasal 31 ayat (1) sampai dengan ayat (5) UUD 1945 menyebutkan sebagai berikut ${ }^{8}$ :

1. Setiap warga negara berhak mendapatkan pendidikan

2. Setiap warga negara wajib mengikuti pendidikan dasar dan pemerintah wajib membiayainya

3. Pemerintah mengusahakan dan menyelengggarakan satu sistem pendidikan nasional, yang meningkatakan keimanan dan ketakwaan serta akhlak mulia dalam rangka mencerdaskan kehidupan bangsa, yang diatur dengan undang-undang.

4. Negara memprioritaskan anggaran pendidikan sekurang-kurangnya dua puluh persen dari anggaran pendapatan dan belanja negara serta dari anggaran pendapatan dan belanja daerah untuk memenuhi kebutuhan penyelenggaraan pendidikan nasional.

5. Pemerintah memajukan ilmu pengetahuan dan teknologi dengan menjunjung tinggi nilai-nilai agama dan persatuan bangsa untuk kemajuan peradaban serta kesejahteraan umat manusia

Secara konstitusi, jelas semua urusan pendidikan menjadi kewajiban dan tanggung jawan pemerintah, namun bukan berarti masyarakat tidak boleh lepas tanggung jawab. Peran serta dan tanggung jawab masyarakat sangat dibutuhkan dalam mengadakan perubahan, pengembangkan serta penyeleggaraan pendidikan.

Pasal 3 UU Nomor 20 tahun 2003 tentang Sistem Pendidikan Nasional menyebutkan bahwa :

Pendidikan nasional berfungsi mengembangkan kemampuan dan membentuk watak serta peradaban bangsa yang bermartabat dalam rangka mencerdaskan kehidupan bangsa, bertujuan untuk berkembangnya potensi peserta didik agar menjadi manusia yang beriman dan bertkwa kepada Tuhan Yang Maha Esa, berakhlak mulia,

${ }^{8}$ Muntoha, Pendidikan Dalam Perspektif Hukum (Antara Harapan Dan Realitas), Jurnal Madaniyah, ISSN 2086-3462, Volume 1 Edisi X Januari 2016 , hlm 91 
sehat, berilmu, cakap, kreatif, mandiri, dan menjadi warga negara yang demokratis serta bertanggungjawab.

Sesunggunya sistem pendidikan nasioanal telah diatur secara lengkap dalam konstitusi, akan tetapi belum terimplementasi dengan baik dan sesuai secara penuh. Apalagi dalam perkembangannya selalu dipengaruhi oleh perkembangan politik kekuasaan dan sudah menjadi kebiasaan yang melembaga ketika bergantinya kekuasaan, berganti pula sistem atau kebijakan dalam pendidikan, baik aturan, kurikulum maupun hal-hal lain yang berkaitan dengan pendidikan, sehingga proses belajar mengajar maupun hasil proses tersebut belum bisa menghasilkan sesuai dengan yang harapkan dan yang dicita-citakan, serta tujuan pendidikan belum bisa dicapai secara maksimal.

Selain teori negara hukum akan digunakan pula teori penegakan hukum. Pada hakekatnya hukum adalah perlindungan kepentingan manusia, yang merupakan pedoman tentang bagaimana sepatutnya orang harus bertindak. ${ }^{9}$ Namun hukum tidak sekedar merupakan pedoman saja, sekedar dekorasim ataupun perhiasan semata, hukum haruslah dilaksanakan, ditaati, dipertahankan dan ditegakkan. Pelaksanaan hukum dalam kehidupan masyarakat sehari-hari mempunyai arti yang sangat penting, dikarenakan apa yang menjadi tujuan hukum justru terletak pada pelaksanaan hukum tersebut. Ketertiban dan ketentraman di dalam masyarakat hanya akan dapat terwujud apabila hukum dapat dilaksanakan, apabila tidak maka peraturan hukum yang hanya berisi susunan kata-kata yang tidak mempunyai makna dalam kehidupan masyarakat (peraturan hukum yang demikian akan menjadi mati sendiri)

Pelaksanaan hukum dapat berlangsung di dalam masyarakat secara normal apabila setiap individu menaati dengan kesadaran apa yang ditentukan hukum tersebut sebagai suatu keharusan arau sebagai sesuatu yang memang sebaiknya. Pelaksanaan hukum dapat terjadi dikarenakan pelanggaran hukum, yaitu dengan menegakkan hukum tersebut dengan bantuan alat-alat perlengkapan negara. Sebagaimana pendapat sacipto Rahadjo, yang menyatakan bahwa ${ }^{10}$ Penegakan hukum merupakan suatu usaha untuk mewujudkan ide-ide tentang keadilan. Kepastian hukum dan kemanfaatan sosial menjadi kenyataan. Proses perwujudan ide-ide itulah yang merupakan hakikat dari penegakan hukum. Selain itu menurut Soerjono Soekanto, Penegakan hukum adalah kegiatan menterasikan hubungan nilai-nilai yang terjabarkan di dalam kaidah-kaidah yang mantap dan mengejawantah dan sikap tindak sebagai rangkaian penjabaran nilai tahap akahir, untuk menciptakan, memelihara dan mempertahankan kedamaian pergaulan hidup. ${ }^{11}$

Secara khusus P. de Haan menguraikan pandangan bahwa penegakan hukum seringkali diartikan sebagai penerapan sanksi, di mana sanksi

${ }^{9}$ Sudikno Metokusumo, Bunga Rampai ilmu Hukum, Penerbit Liberty, Yogyakarta, 2003, hlm. 107.

${ }^{10}$ Riduan Syahrabi, Rangkuman Intisari Ilmu Hukum, PT. Citra Aditya Bakti, Bandung, 2001, hlm., 192

${ }^{11}$ Soerjono Soekanto, Faktor Yang Mempengaruhi Penegakan Hukum, Rajawali Press, Jakarta, 2003 hlm., 3. 
merupakan penerapan alat kekuasaan (machtsmiddelen) sebagai reaksi atas pelanggaran norma hukum. Hakekat penegakan hukum adalah merupakan upaya menyelelaraskan nilai-nilai hukum dengan merefleksikan di dalam bersikap dan bertindak di dalam pergaulan bermasyarakat demi terwujudnya keadilan, kepastian hukum dan kemanfaatan keadilan dengan menerapkan sanksi-sanksi. ${ }^{12}$

Penegakan hukum (law enforcement) sebagai bagian dari yuridiksi negara, berisikan tentang beberapa hal, antara lain: Pertama, wewenang membuat aturan-aturan hukum untuk mengatur berbagai kepentingan nasional (juridiction of legislation atau juridiction of law); Kedua, wewenang menegakkan aturan yang berlaku (juridiction to enforce of law). Dengan terselenggaranya kegiatan-kegiatan penegakan hukum oleh negara atau aparatnya pada hakekatnya adalah terselenggaranya penegakan kedaulatan negara tersebut. Di dalam penegakan hukum setidaknya ada 3 (tiga) hal yang harus diperhatikan, yaitu: kepastian hukum, kemanfaatan (ketertiban dan ketentraman) dan keadilan.

1. Kepastian Hukum:

Hukum dilaksanakan dan ditegakkan setiap orang yang menginginkan untuk dapat ditetapkannya hukum terhadap peristiwa konkret yang terjadi, bagaimana hukumnya, itulah yang harus diberlakukan pada setiap peristiwa yang terjadi. Pada dasarnya tidak ada penyimpangan. Bagaimanpun juga hukum harus ditegakkan, sampai timbul perumpamaan " meskipun besok hari kiamat, hukum harus tetap ditegakkan", inilah yang diinginkan kepastian hukum yang memiliki tujuan adanya ketertiban di dalam masyarakat.

2. Kemanfaatan Hukum

Pelaksanaan dan penegakan hukum juga harus memperhatikan kemanfaatannya dan kegunaannya di dalam masyarakat. Sebab hukum dibuat untuk kepentingan masyarakat, karenanya pelaksanaan dan penegakan hukum haruslah dapat memberikan manfaat di dalam masyarakat. Hal yang haruslah dihindari adalah pelaksanaan dan penegakan hukum yang merugikan masyarakat yang pada akhirnya menimbulkan keresahan.

3. Keadilan Hukum

John Rawls menyatakan bahwa, keadilan merupakan sebuah nilai yang mewujudkan keseimbangan antara bagian-bagian dalam kesatuan, antara tujuan-tujuan pribadi dan tujuan bersama. ${ }^{13}$ Dalam konteks keadilan hukum, mengandung 2 (dua) makna: Pertama, prinsip kesamaan; pada dasarnya menuntut adanya pembagian secara merata dan proporsional, misalnya apabila ada kegiatan pribadi untung 100 di mana saya mendapat untung 80 dan kawan 20, hal ini dianggap adil dengan kata lain semua harus mendapat untung yang sama dari pada tidak untung sama sekali; Kedua, prinsip $2005 \mathrm{hlm} .1$.

12 Philipus M. Hadjon, Penegakan Hukum Adminstrasi, Penerbit Yurika, Jakarta,

13 Theo Huijbers, Filsafat Hukum dalam Lintasan Sejarah, Penerbit Kanisius, Yogyakarta, 2007, hlm. 197-200. 
ketidaksamaan, situasi ketidaksamaan harus diberikan aturan sedemikian rupa sehingga menguntungkan golongan masyarakat yang paling lemah dengan syarat: a) situasi ketidaksamaan menjamin maksimum minimorum, artinya situasi masyarakat harus sedemikian sehingga dihasilkan untung paling tinggi yang mungkin dihasilkan bagi golongan-golongan kecil, b) ketidaksamaan diikat pada jabatan-jabatan yang terbuka, artinya kepada semua orang diberikan peluang yang sama besar dalam hidup, perbedaan berdasarkan ras, kulit, agama, dan lainnya ditolak. Sepaham dengan apa yang disampaikan oleh John Rawls, Soerjono Soekanto mengatakan bahwa keadilan pada hakekatnya didasarkan pada 2 (dua) hal: Pertama, asas kesamarataan, di mana setiap orang mendapat bagian yang sama; ${ }^{14}$ Kedua, didasarkan pada kebutuhan sehingga menghasilkan kesebandingan halaman biasanya diterapkan dalam bidang hukum.

Pelaksanaan dan penegakan hukum juga harus mencapai keadilan, peraturan hukum tidak identik dengan keadilan, karenanya peraturan hukum yang bersifat umum dan mengikat setiap orang, maka penerapannya harus mempertimbangkan fakta dan keadaan yang terdapat pada setiap kasus. Misalnya, A sebagai pelaku pencurian seekor kambing dan B juga sebagai pelaku pencurian seekor kambing yang sama besarnya, tidak niscaya dihukum penjara yang sama lamanya. Namun kadang kala sangat mungkin berbeda , karena berat ringannya macam fakta dan keadaan pada peristiwa pencuriaan itu, misalnya dipertimbangkan: mengapa sampai mencuri? siapa yang menjadi korban pencurian? siapa yang melakukan pencurian?di mana dan bagaimana barang dicuri? dan sebagainya, yang semuanya harus dipertimbangkan oleh aparat penegak hukum, terutama oleh Hakim yang menjatuhi putusan. Jadi keadilan itu sifatnya kasuitis. Selain itu perlu diperhatikan di sini, bahwa hukum yang dilaksanakan dan ditegakkan haruslah hukum yang mengandung nilai-nilai keadilan. Untuk menjelaskan hakekat penegakan hukum itu, Soejono Soekanto membuat uraian, sebagaimana berikut: manusia di dalam pergaulan hidup, pada dasarnya memiliki pandangan tertentu mengenai apa yang baik dan apa yang buruk. Pandangan-pendangan tersebut senantiasa terwujud dalam pasangan-pasangan tertentu, sehingga ada pasangan nilai ketertiban dengan nilai ketentraman, padangan nilai kelestarian dengan nilai perubahan dan nilai sebagainya. Dalam penegakan hukum pasangan nilai tersebut perlu "diserasikan" misalnya perlu penyerasian antara ketertiban dan nilai ketentraman. Pasangan nilai-nilai yang telah diserasikan tersebut, karena nilainilai sifatnya abstrak, memerlukan penjabaran lebih konkret dalam bentuk kaidah-kaidah, yang mungkin berisikan suruhan, larangan, atau kebolehan.

Kaidah-kaidah hukum menjadi pedoman atau patokan bagi perilaku atau sikap tindak yang dianggap pantas, atau seharusnya. Perilaku atau sikap tindak tersebut bertujuan untuk menciptakan, memelihara dan mempertahankan kedamaian. Demikian konkretisasi dari penegakan hukum secara konsepsional. Gangguan terhadap penegakan mungkin terjadi, apabila ada ketidakserasian

14 Soejono Soekanto, Pokok-Pokok Sosiologi Hukum, Penerbit CV. Rajawali, Jakarta, 1986, hlm. 21 
antara tritunggal nilai, kaidah hukum dan perilaku, gangguan tersebut terjadi apabila terjadi ketidak serasian antara nilai-nilai yang berpasangan, yang menjelma dalam kaidah-kaidah yang bersimpang siur, dan pola perilaku yang tidak terarah yang menggugah kedamaian pergaulan hidup. Oleh karena itu Soerjono Soekanto, menyatakan penegakan hukum bukan semata-mata berarti pelaksanaan perundang-undangan, meskipun dalam kenyataan di Indonesia kecenderungannya adalah demikian, sehingga pengertian "law enforcement" begitu populer. ${ }^{15}$ Bahkan ada kecenderungan untuk mengartikan penegakan hukum sebagai pelaksanaan keputusan-keputusan pengadilan. Pengertian yang sempit ini jelas mengandung kelemahan, sebab pelaksanaan perundangundangan atau keputusan pengadilan, bila terjadi malahan justru menganggu kedamaian dalam pergaulan hidup. Penegakan hukum di Indonesia, harus berarti penegakan hukum yang mengandung nilai-nilai yang sesuai dengan Pancasila dan Undang-Undang Dasar 1945. Hal ini harus disadari karena hukum yang berlaku di Indonesia saat ini masih banyak yang merupakan warisan Pemerintah Hindia Belanda, seperti Kitab Undang-Undang Hukum Pidana (wetboek van koophandel), Hukum Acara Perdata yang termuat dalam (Herziene Inlandsch Reglemen) dan (Rechtsreglement voor de buitengewwesten) yang lazim disebut hukum pokok (basic law), semuanya merupakan peninggalan sebelum perang. Sebagai produk hukum masa lampau, yang dibutakan untuk sedikit banyak atau keseluruhan kepentingan penjajahan atau falsafah kapitalis, materiilistis, individualistis, maka peraturan-peraturan hukum peninggalan kolonial tersebut tidak selamanya sesuai dengan rasa keadilan masyarakat Indonesia yang sekarang sudah berada dalam alam kemerdekaan dan pembangunan.

Penegakan hukum terhadap larangan pungutan biaya pendidikan diatur dalam Peraturan Menteri Pendidikan dan Kebudayaan Nomor 44 Tahun 2012 Tentang Pungutan Dan Sumbangan Biaya Pendidikan Pada Satuan Dasar, ada empat jenis biaya yaitu biaya investasi; biaya operasi; bantuan biaya pendidikan; dan beasiswa. Biaya operasional dan bantuan biaya pendidikan sudah ditutupi oleh Biaya Operasional Sekolah (BOS), Beasiswa dan biaya investasi yang menjadi tanggung jawab pemerintah, misalnya biaya untuk pembangunan perpustakaan, rehab gedung sekolah, oleh karena itu, sekolah negeri dilarang melakukan pungutan.

Sekolah yang di selenggarakan oleh pemerintah pusat atau daerah (Sekolah Negeri ) tidak di perbolehkan melakukan pungutan terhadap wali murid. Hal ini sebagaimana di atur dalam Undang - Undang Nomor 20 tahun 2003 tentang Sistem Pendidikan Nasional Dan Peraturan Menteri Pendidikan Dan Kebudayaan No 44 tahun 2012 tentang Pungutan Dan Sumbangan Biaya Pendidikan Pada Satuan Dasar. Pasal 9 ayat (1) Peraturan Menteri Pendidikan Dan Kebudayaan No 44 tahun 2012 tentang Pungutan Dan Sumbangan Biaya Pendidikan Pada Satuan Dasar menyatakan : "satuan pendidikan sadar yang di selenggarakan oleh pemerintah dan/atau pemerintah daerah di larang memungut biaya satuan pendidikan". Dalam undang-undang dan peraturan

\footnotetext{
${ }^{15}$ Soerjono Soekanto, Faktor yang Mempengaruhi ...Op.Cit, hlm. 5.
} 
menteri tersebut dijelaskan bahwa larangan di lakukannya pungutan jenis apapun di sekolah negeri saat lulus atau pun penerimaan siswa baru mulai dari tingkat SD dan SMP. Pemerintah menjamin pendidikan dasar tanpa pungutan ,terutama SD dan SMP . Aturan itu juga memuat ancaman sanksi bagi yang melanggar . Dalam masalah ini secara umum bagi pihak yang melakukan pungutan liar maka pihak di anggap menyalahgunakan jabatan, dan atas tindakan tersebut dengan jelas melanggar Pasal 423 KUHP dengan ancaman hukuman maksimal 6 tahun penjara.

\section{E. Metode Penelitian}

Dalam rangka memperoleh dan menganalisis setiap informasi yang bersifat ilmiah, tentunya dibutuhkan suatu metode dengan tujuan agar suatu karya ilmiah itu memiliki susunan yang sistematis, terarah dan konsisten. ${ }^{16}$ Penelitian ini adalah penelitian hukum dengan pertimbangan bahwa titik tolak penelitian adalah mengkaji pungutan liar pada penyelenggara pendidikan dasar. Pendekatan yang digunakan dalam penelitian adalah pendekatan undangundang (statue approach), pendekatan sejarah (historys approach)

Metode Pendekatan yang digunakan dalam penelitian ini adalah pendekatan yuridis normatif, yaitu dengan mengkaji atau menganalisis data sekunder yang berupa bahan-bahan hukum sekunder dengan memahami hukum sebagai perangkat peraturan atau norma-norma positif di dalam sistem perundang-undangan yang mengatur mengenai permasalahan dalam penelitian ini. Jadi penelitian ini dipahami sebagai penelitian kepustakaan, yaitu penelitian terhadap data sekunder. ${ }^{17}$

Tahap-tahap penelitian yang dilakukan adalah :

a. Studi Kepustakaan, yaitu mempelajari literatur-literatur untuk memperoleh data sekunder, yang terdiri dari bahan hukum primer, bahan hukum sekunder dan bahan hukum tertier. Bahan hukum primer adalah bahan hukum yang bersifat autoritatif (mempunyai otoritas), dan bahan-bahan hukum yang mengikat, yakni norma (dasar) atau kaidah dasar dan peraturan-peraturan dasar, seperti Undang-Undang Dasar 1945, serta peraturan perundang-undangan yang berkaitan dengan pungutan liar pungutan liar pada penyelenggara pendidikan dasar, seperti UUD 1945, KUHP, Undang - Undang Nomor 20 tahun 2003 tentang Sistem Pendidikan Nasional Dan Peraturan Menteri Pendidikan Dan Kebudayaan No 44 tahun 2012 tentang Pungutan Dan Sumbangan Biaya Pendidikan Pada Satuan Dasar, Peraturan Menteri Pendidikan dan Kebudayaan Nomor 75 Tahun 2016 tentang Komite Sekolah. Bahan hukum sekunder adalah bahan hukum yang memberikan penjelasan mengenai bahan hukum primer, berupa hasilhasil penelitian, karangan ilmiah dari kalangan hukum, dan penelitianpenelitian lain yang relevan dengan penelitian ini. Kemudian bahan hukum tertier adalah bahan yang memberikan petunjuk ataupun penjelasan terhadap bahan hukum primer dan bahan hukum sekunder, berupa kamus,

${ }^{16}$ Soerjono Soekanto \& Sri Mamudji, Penelitian Hukum Normatif: Suatu Tinjauan Singkat, Rajawali Press, Jakarta, 1990 hlm. 1.

${ }^{17} \mathrm{Ibid}$, hlm. 15. 
ensiklopedia, majalah, surat kabar dan sebagainya yang dipergunakan untuk melengkapi ataupun menunjang data penelitian ini.

b. Studi Lapangan, yaitu dilakukan dalam rangka memperoleh data primer yang menunjang data sekunder, sehingga dari data primer akan dapat diketahui bagaimana pelaksanaan pungutan liar pada penyelenggara pendidikan dasar

Setelah data sekunder dan primer terkumpul, kemudian diadakan analisis secara kualitatif yaitu menganalisis data berupa uraian-uraian yang sistematis tanpa mempergunakan bagan-bagan dan rumus statistik

\section{F. Hasil Penelitian dan Pembahasan}

\section{Kewenangan penyelenggara pendidikan menarik pungutan atas dasar} kesepakatan dengan orangtua/wali siswa

Kewenangan merupakan satu landasan seseorang dapat dibenarkan melakukan tindakan atau perbuatan dalam bentuk apapun. Kewenangan tersebut tentu haruslah sesuai dengan peraturan perundang-undangan yang berlaku. Sebab, semua itu tidak terlepas dari prinsip yang secara tegas diadopsi oleh negara Indonesia yakni sebagai negara hukum ${ }^{18}$.

Salah satu prinsip negara hukum adalah prinsip legalitas (legaliteitsbeginsel), yang berarti bahwa setiap penyelenggaraan urusan pemerintahan itu harus didasarkan pada wewenang yang diberikan oleh peraturan perundang-undangan yang berlaku. Asas ini menentukan bahwa tanpa dasar wewenang yang diberikan oleh suatu peraturan perundangundangan yang berlaku, maka segala macam aparat pemerintah tidak akan memiliki wewenang yang dapat mempengaruhi atau mengubah keadaan atau posisi hukum warga masyarakatnya. Asas legalitas menurut Sjachran Basah, berarti upaya mewujudkan duet integral secara harmonis antara paham kedaulatan hukum dan paham kedaulatan rakyat berdasarkan prinsip monodualitis selaku pilar-pilar, yang sifatnya konstitutif. ${ }^{19}$ Di sinilah letak eratnya hubungan antara kajian asas legalitas dan juga wewenang yang didapatkan aparatur pemerintahan.

Ditegaskan dalam Pasal 1 ayat (3) UUD NRI 1945 disebutkan "Negara Indonesia adalah Negara hukum". Negara hukum memiliki makna bahwa tindakan dalam bentuk apa pun dilakukan oleh siapapun harus sesuai dengan asas legalitas, lebih-lebih kepada penyelenggara negara dan penyelenggara pendidikan. Asas legalitas merupakan prinsip negara hukum yang sering dirumuskan dengan ungkapan "het beginsel van wetmatigheid van bestuur" yakni prinsip keabsahan pemerintahan atau penyelenggara negara. Artinya, asas legalitas sendiri menentukan bahwa semua ketentuan keterikatan warga negara harus didasarkan pada undang-undang (het

18 Johan Rahmatulloh, Legalitas Kewenangan Penyelenggara Pendidikan dalam Menarik Pungutan di Satuan Pendidikan Dasar, Jurnal Integritas, Volume 3 Nomor 2 Desember 2017, hlm 144

19 Sjachran Basah, Eksistensi dan Tolok Ukur Peradilan Administrasi Negara di Indonesia, Alumni, Bandung, 1997, hlm. 32 
legaliteitsbeginsel houdt in dat alle (algemene) de burgers bindende bepalingen op de wet moeten berusten). ${ }^{20}$

Dalam pengertian yang luas bahwa siapapun yang terikat dengan hukum tertulis tersebut tidak hanya sebatas kepada undang-undang saja, melainkan seluruh peraturan perundang-undangan sesuai dengan jenjangnya. Sebab hukum tertulis itu sendiri memiliki tingkatan atau jenjangnya sebagaimana pendapat yang dikemukakan oleh Hans Kelsen. Menurut Hans Kelsen sebagaimana dikutip oleh Maria Farida Indrati yakni:

"Norma hukum selalu berjenjang, di mana norma yang di bawah berlaku, bersumber dan berdasar pada norma yang lebih tinggi, norma yang lebih tinggi berlaku, bersumber dan berdasar pada norma yang lebih tinggi lagi, sampai pada suatu norma yang tertinggi yang disebut norma dasar (grundnorm)". ${ }^{21}$

Apabila seseorang yang memiliki kewenangan dalam hal ini aparatur negara bertindak atau melakukan atau mengambil suatu keputusan tidak sesuai dengan peraturan perundang-undangan sebagaimana disebutkan di atas, maka seseorang tersebut dapat dikatakan telah menyalahgunakaan kewenangannya (detournement de pouvoir) kecuali ditentukan oleh keadaan-keadaan khusus atau darurat yang harus mengambil keputusan atau bertindak dengan segera. Sebagaimana Philipus M. Hadjon yang mengutip Putusan Hoge Raad (H.R., 9 Desember 1961) merumuskan yang dimaksud dengan penyalahgunaan wewenang tersebut adalah sebagai berikut:

"Kesewenangan adalah suatu bentuk penyalahgunaan wewenang khusus karena orang yang diberi wewenang itu menggunakannya bertentangan dengan peraturan yang mendasarinya dan berdasarkan pertimbangan yang wajar megenai tujuan peraturan itu, ia tidak memenuhi kepentingan-kepentingan yang harus diperhatikan". 22

Lebih lanjut Philipus M. Hadjon menyatakan rumusan pengertian "detournement de pouvoir" yang pertama kali dalam Arrest Zandvoorts (H.R. 14 Januari 1949) oleh Hoge Raad dikatakan:

"Bahwa ia (Walikota) dalam pada itu menurut desakan lainnya meskipun berasal dari kepentingan umum yaitu desakan yang lain daripada yang menurut tujuan undang-undang pada waktu memilih obyek yang harus dituntut yang harus diperhatikan ia menggunakan wewenangnya untuk tujuan lain daripada tujuan yang diberikan kepada wewenang itu".

\footnotetext{
${ }^{20}$ Ridwan HR, Hukum Administrasi Negara. Rajawali Pers, Jakarta,2011, hlm. 91

${ }^{21}$ Maria Farida Indrati, Ilmu Perundang-undangan Jenis, Fungsi, dan Materi Muatan. Kanisius, Yogyakarta, 2007, hlm. 44.

${ }^{22}$ Amiruddin, Korupsi Dalam Pengadaan Barang dan Jasa, Genta Publishing, Yogyakarta, 2010, hlm. 199
} 
Berdasarkan rumusan penyalahgunaan wewenang di atas, lebih jelas dikemukakan pendapat oleh Jean Rivero dan Waline sebagaimana dikutip oleh Amiruddin diartikan ke dalam tiga wujud, yakni:

a. Penyalahgunaan wewenang untuk melakukan tindakan-tindakan yang bertentangan dengan kepentingan umum atau untuk menguntungkan kepentingan pribadi, kelompok atau golongan;

b. Penyalahgunaan wewenang dalam arti bahwa tindakan pejabat tersebut adalah benar ditujukan untuk kepentingan umum, tetapi menyimpang dari tujuan apa kewenangan tersebut diberikan oleh undang-undang atau peraturan-peraturan lain;

c. Penyalahgunaan wewenang dalam arti menyalahgunakan prosedur yang seharusnya dipergunakan untuk mencapai tujuan tertentu, tetapi telah menggunakan prosedur lain agar terlaksana. ${ }^{23}$

Dengan demikian, kewenangan penyelenggara pendidikan dalam melakukan pungutan pada satuan pendidikan dasar wajib berlandaskan pada peraturan perundang-undangan yang berlaku, agar tindakan atau perbuatan dari pejabatnya tidak bertentangan atau melakukan perbuatan melawan hukum yang mengarah pada penyalahgunaan wewenang dalam melakukan pungutan.

Secara harfiah, pungutan dalam Kamus Bahasa Indonesia dijelaskan bahwa "Pungutan adalah sesuatu yang dipungut, sesuatu yang dipetik, sesuatu yang dikutip". Batasan pengertian pungutan tersebut jika ditelusuri dalam peraturan perundang-undangan, diatur dalam Permendikbud No. 44 Tahun 2012 tentang Pungutan dan Sumbangan Biaya Pendidikan Pada Satuan Pendidikan Dasar. Dalam ketentuan Pasal 1 angka (2) Permendikbud tersebut mendefinisikan sebagai berikut:

Pungutan adalah penerimaan biaya pendidikan baik berupa uang dan/atau barang/jasa pada satuan pendidikan dasar yang berasal dari peserta didik atau orangtua/wali secara langsung yang bersifat wajib, mengikat, serta jumlah dan jangka waktu pemungutannya ditentukan oleh satuan pendidikan dasar.

Lebih lanjut, di mana pungutan memiliki pengertian yang berbeda dengan sumbangan. Dalam ketentuan Pasal 1 angka (3) Permendikbud No 44 Tahun 2012 disebutkan yang dimaksud dengan sumbangan yakni:

Sumbangan adalah penerimaan biaya pendidikan baik berupa uang dan/atau barang/jasa yang diberikan oleh peserta didik, orangtua/wali, perseorangan atau lembaga lainnya kepada satuan pendidikan dasar yang bersifat sukarela, tidak memaksa, tidak mengikat, dan tidak ditentukan oleh satuan pendidikan dasar baik jumlah maupun jangka waktu pemberiannya. 
Pungutan dan sumbangan yang dimaksud di atas sesuai ketentuan Permendikbud No 44 Tahun 2012 diberlakukan khusus untuk siswa satuan pendidikan dasar. Sedangkan, yang dimaksud dengan "satuan pendidikan dasar" adalah sebagaimana ketentuan Pasal 1 angka (1) Permendikbud No 44 Tahun 2012 yakni:

"Satuan pendidikan dasar adalah satuan pendidikan penyelenggara program wajib belajar pendidikan dasar 9 (sembilan) tahun yang meliputi Sekolah Dasar dan Sekolah Menengah Pertama termasuk Sekolah Dasar Luar Biasa, Sekolah Menengah Pertama Luar Biasa, dan Sekolah Menengah Pertama Terbuka".

Dana dalam bentuk uang merupakan instrumen penting dalam memenuhi kebutuhan dalam setiap pelaksanaan atau penyelenggaraan proses belajar mengajar. Sebab, uang merupakan bagian dari sistem pendidikan nasional yang besar pengaruhnya untuk kemajuan pendidikan. Secara harfiah, sistem adalah satu kesatuan komponen yang saling berkaitan atau berhubungan dan saling memengaruhi untuk mencapai suatu tujuan tertentu. Artinya, apabila satu komponen tidak berjalan atau tidak berfungsi maka akan memengaruhi komponen yang lainnya

Pendanaan sekolah yang diperoleh dari pungutan tersebut dapat ditelusuri Peraturan Pemerintah Nomor 48 Tahun 2008 tentang Pendanaan Pendidikan. Ditegaskan dalam Pasal 2 ayat (1) yakni: "Pendanaan pendidikan menjadi tanggung jawab bersama antara pemerintah, pemerintah daerah, dan masyarakat". Dan dalam Pasal 2 ayat (2) menyebutkan bahwa Masyarakat sebagaimana dimaksud pada ayat (1) meliputi:

a. penyelenggara atau satuan pendidikan yang didirikanmasyarakat

b. peserta didik, orang tua atau wali peserta didik ; dan

c. pihak lain selain yang di maksud dalam huruf a dan huruf b yang mempunyai perhatian dan peranan dalam bidang pendidikan .

Selanjutnya dalam Pasal 51 PP No 48 Tahun 2008, disebutkan bahwa sumber pendanaan sekolah adalah sebagai berikut: (1) Pendanaan pendidikan bersumber dari Pemerintah, pemerintah daerah, dan masyarakat; (2) Dana pendidikan pemerintah daerah sebagaimana dimaksud pada ayat (1) dapat bersumber dari: a) anggaran Pemerintah; b) anggaran pemerintah daerah; c) bantuan pihak asing yang tidak mengikat; dan/atau d) sumber lain yang sah. Ditegaskan kembali dalam Pasal 51 ayat (5) berbunyi sebagai berikut:

"Dana pendidikan satuan pendidikan yang diselenggarakan oleh pemerintah daerah dapat bersumber dari: a) bantuan pemerintah daerah; b) bantuan Pemerintah; c) pungutan dari peserta didik atau orangtua/walinya yang dilaksanakan sesuai peraturan perundangundangan; d) bantuan dari pemangku kepentingan satuan pendidikan di luar peserta didik atau orangtua/walinya; e) bantuan pihak asing yang tidak mengikat; dan/atau f) sumber lainnya yang sah". 
Apabila kita diamati rumusan ketentuan Pasal 51 ayat (5) Peraturan Pemerintah tersebut di atas, pendanaan yang bersumber dari "pungutan dari peserta didik" masih bersifat umum untuk semua satuan pendidikan, artinya tidak secara eksplisit menyebutkan diberlakukan kepada satuan pendidikan dasar. Namun secara eksplisit juga mengenai pungutan dalam satuan pendidikan dasar tersebut sebagaimana diatur dalam Pasal 9 ayat (1) Permendikbud No 44 Tahun 2012, secara lengkap berbunyi, "satuan pendidikan dasar yang diselenggarakan oleh pemerintah, dan/atau pemerintah daerah dilarang memungut biaya satuan pendidikan". Akan tetapi, meskipun dilarang melakukan pungutan, pihak penyelenggara pendidikan masih bisa mendapatkan pendanaan dengan jalan lain yang bersumber dari orang tua atau wali siswa yakni melalui "sumbangan".

Pada Pasal 10 ayat (2) Peraturan Menteri Pendidikan Dan Kebudayaan Republik Indonesia Nomor 75 Tahun 2016 Tentang Komite Sekolah disebutkan bahwa penggalangan dana dan sumber daya pendidikan lainnya sebagaimana dimaksud pada ayat (1) berbentuk bantuan dan/atau sumbangan, bukan pungutan. Bantuan dan sumbangan bersifat sukarela, sedangkan pungutan bersifat memaksa. Definisi sumbangan, bantuan dan pungutan ini masih kurang dipahami siswa dan orang tua. Bantuan didefinisikan sebagai pemberian uang/barang/jasa oleh pemangku kepentingan satuan pendidikan di luar peserta didik atau orang tua/wali, dengan syarat yang disepakati para pihak. Sumbangan didefinisikan sebagai pemberian uang/barang/jasa oleh peserta didik, orang tua/wali baik perseorangan maupun bersama-sama, masyarakat atau lembaga secara sukarela, dan tidak mengikat satuan pendidikan. Sedangkan, pungutan didefinisikan sebagai penarikan uang oleh Sekolah kepada peserta didik, orangtua/walinya yang bersifat wajib, mengikat, serta jumlah dan jangka waktu pemungutannya ditentukan.

Berdasarkan uraian di atas, kewenangan pihak sekolah melakukan "pungutan" kepada orang tua atau wali siswa dalam satuan pendidikan dasar dalam bentuk apapun sudah limitatif tidak dibenarkan untuk dilakukan, kecuali penarikan yang dilakukan atas dasar sumbernya melalui "sumbangan". Apabila, pihak penyelenggara pendidikan satuan pendidikan dasar melakukan pungutan, maka perbuatan tersebut bertentangan dengan Permendikbud No 44 Tahun 2012. Sehingga, perbuatan tersebut dapat ditindaklanjuti melalui proses penegakan hukum. ${ }^{24}$

\section{Faktor-faktor yang menjadi penyebab terjadinya Pungutan Liar di Sekolah Menengah Pertama}

Salah satu bentuk tindak pidana korupsi yang sering terjadi dalam kehidupan sehari-hari adalah pungutan liar (pungli). Pungutan liar dilarang dalam Undang-Undang Nomor 31 Tahun 1999 Jo Undang-Undang No 20 Tahun 2001 tentang Pemberantasan Tindak Pidana Korupsi.

\footnotetext{
${ }^{24}$ Ibid, hlm 150
} 
Perbuatan-perbuatan yang disebut sebagai perbuatan pungutan liar sebenarnya merupakan suatu gejala sosial yang telah ada di Indonesia, sejak Indonesia masih dalam masa penjajahan dan bahkan jauh sebelum itu. Namun penamaan perbuatan itu sebagai perbuatan pungli, secara nasional baru diperkenalkan pada bulan September 1977, yaitu saat Komando Pemulihan Keamanan dan Ketertiban disingkat Kaskopkamtib yang bertindak selaku Kepala Operasi Tertib bersama Menpan dengan gencar melancarkan Operasi Tertib (OPSTIB), yang sasaran utamanya adalah pungli

Pungli lahir dari tingginya tingkat ketidakpastian pelayanan sebagai akibat adanya prosedur pelayanan yang panjang dan melelahkan menjadi penyebab dari semakin banyaknya masyarakat yang menyerah ketika berhadapan dengan pelayanan publik yang korupsi. Hal ini merupakan salah satu faktor yang menyebabkan masyarakat cenderung semakin toleran terhadap praktik pungutan liar dalam penyelenggaraan pelayanan publik. ${ }^{25}$

Sektor pelayanan publik yang dikelola pemerintah, baik departemen, lembaga pemerintah non departemen, maupun pemerintah daerah, seperti pelayanan pajak, perizinan, investasi, pembuatan Kartu Tanda Penduduk (KTP), Surat Izin Mengemudi (SIM), Surat Tanda Nomor Kendaraan (STNK), Izin Mendirikan Bangunan (IMB), transportasi, akta, sertifikat tanah, listrik, air, telepon dan sebagainya merupakan sektor yang rentan terjadinya pungutan liar, karena berkaitan langsung dengan kepentingan masyarakat. Di sektor pelayanan publik terjadi hubungan antar domain, yakni pemerintah atau birokrasi sebagai

penyelenggara pemerintahan, sektor usaha, dan masyarakat umum. ${ }^{26}$ Ironisnya, lembaga Pendidikan yang notabene merupakan lembaga yang dituntut melahirkan insan-insan yang berbudi pekerti luhur pun tak luput dari epidemik pungutan liar ini.

Akhir-akhir ini pungutan liar di sekolah dengan berbagai modus operandinya sudah menjadi rahasia umum bagi masyarakat dan hal ini sulit dicegah karena melibatkan stakeholders pada lembaga tersebut. Padahal telah ada Peraturan Menteri Pendidikan dan Kebudayaan (Permendikbud) Nomor 44 Tahun 2012 tentang Pungutan Dan Sumbangan Biaya Pendidikan Pada Satuan Pendidikan Dasar. Di antara alasan yang sering dijadikan tameng dalam melancarkan aksi penyimpangan dimaksud antara lain "demi meningkatkan kualitas, untuk menambah fasilitas (sarpras) sekolah, studi tour dan sebagainya" dan hal itu notabene melibatkan komite sekolah sebagai jurus untuk memuluskan aksi tersebut.Hal ini merupakan konsekuensi logis dari upaya mencapai standart mutu pendidikan yang telah

25 BPKP.Upaya Pencegahan dan Penanggulangan Korupsi pada Pengelolaan Pelayanan Masyarakat, Tim Pengkajian SPKN RI, Jakarta,2002, hlm. 6.

${ }^{26}$ Nabila Zoraya Rahmatullah, Tinjauan Kriminilogis Terhadap Pungutan Liar Oleh Penyelenggara Pendidikan Di Sekolah Yang Berada Di Wilayah Hukum Kota Makassar (Tahun 2011-2013), Skripsi, Program Kekhususan Hukum Pidana Fakultas Hukum Universitas Hasanuddin Makassar 2014, hlm 3 
dicanangkan oleh pemerintah yaitu meningkatkan kualitas pendidikan dengan memberikan ruang gerak yang cukup luas bagi pengelola lembagalembaga pendidikan untuk berkreasi guna menunjukkan eksistensinya di kancah nasional.

Pungutan yang diberlakukan pihak sekolah antara lain untuk keperluan seragam, operasional, bangunan, buku, dana koordinasi, internet, koperasi, amal jariyah, formulir pendaftaran, perpisahan guru, praktek, Sumbangan Penyelenggaraan Pendidikan (SPP), administrasi rapor, ekstrakurikuler, sumbangan pengembangan institusi, uang pangkal dan pungutan liar lainnya. Selain pungutan liar, masyarakat juga menyampaikan keluhan terhadap proses penerimaan siswa baru (PSB) yang tidak tersosialisasi dengan baik. Mereka mengeluhkan kurangnya informasi tentang persyaratan dan jangka waktu pelaksanaan PSB. Selain itu, mereka juga mengeluhkan mengenai PSB Online yang tidak transparan, proses seleksi diskriminatif, adanya titipan anak pejabat.

Sungguh mengerikan dan ironis tentang masalah yang terjadi di dunia pendidikan ini. Di tengah-tengat gencarnya upaya pemberantasan buta huruf, menggencarkan wajib sekolah sembilan tahun dan tanpa dipungut biaya bagi kalangan tertentu. Nyatanya, masih banyak lembaga pendidikan tertentu yang akrab dengan budaya pungutan liar. Alih-alih peningkatan kualitas. Padahal menuntut ilmu secara formal merupakan sektor strategis dan kunci bagi bangsa ini untuk menapakan kaki ke arah kehidupan bangsa yang lebih baik.

Terjadinya pungutan liar tentu ada penyebabnya, Faktor penyebab pungli secara umum dapat diklasifikasikan menjadi dua macam, yaitu faktor internal dan faktor eksternal.

Faktor internal berkaitan dengan pelaku pungli sebagai pemegang amanat berupa jabatan dan wewenang yang diembannya, antara lain:

a. Ingin memperoleh kemawan hidup

b. Kondisi sosial ekonomi

c. Lemahnya iman dari pelaku pungli

d. Penyalahgunaan kekuasaan dan wewewnang

e. Rendahnya pendapatan penyelenggara negara

f. Kemiskinan dan keserakahan

g. Budaya memberi upeti

h. Imbalan dan hadiah

i. Apatis/tidak mau tahu

j. Gagalnya pendidikan agama dan etika

Terhadap faktor penyebab pungli yang disebutkan terakhir, gagalnya pendidikan agama dan etika, berasal dari pemikiran Franz Magnis Suseno, yang mengatakan bahwa agama telah gagal menjadi pembendung moral bangsa dalam mencegah pungli karena perilaku masyarakat yang memeluk agama itu sendiri. Pemeluk agama menganggap bahwa agama hanya berkutat pada masalah bagaimana cara beribadah saja sehingga agama nyaris tidak berfungsi dalam memainkan peran sosial. Menurut Franz, 
sebenarnya agama bisa memainkan peran yang lebih besar dalam konteks kehidupan sosial dibandingkan institusi lainnya. Sebab, agama memiliki relasi atau hubungan emosional dengan para pemeluknya. Jika kekuatan relasi emosional yang dimiliki pemeluk agama diterapkan dengan benar, bisa menyadarkan umat bahwa pungutan liar dapat membawa dampak yang sangat buruk. ${ }^{27}$

Sedangkan faktor eksternal berupa sistem pemerintahan dan kepemimpinan serta pengawasan yang tidak seimbang sehingga bisa membuka peluang terjadinya pungli. Yaitu:

a. Kelemahan mekanisme organisasi

b. Penegakan hukum yang tidak konsisten

c. Lemahnya pengawasan

d. Budaya permisif/serba membolehkan

Disamping faktor di atas, faktor penyebab sering terjadinya pungutan pendidikan di SMPN adalah minimnya transparansi publik dalam pengelolaan dana BOS. Wali murid tidak mengetahui kepala sekolah menggunakan dana BOS yang tidak sesuai dengan anjuran peraturan, sehingga wali murid nihil pengetahuan mengenai pengelolaan dana BOS di SMPN. Dalam petunjuk teknis dana BOS sudah ditetapkan bahwa sekolah harus mengelola dana BOS secara bertanggung jawab dan transparan dan mengumumkan besar dana yang diterima dan dikelola oleh sekolah dan rencana penggunaan dana BOS (RKAS) di papan pengumuman sekolah yang ditandatangani oleh Kepala Sekolah, Bendahara dan Ketua Komite Sekolah. terkait pengumuman di papan pengumuman tidak pernah terlaksana di SMPN. Tertutupnya sekolah mengenai pelaporan dana BOS kurang beralasan, karena tidak bisa menunjukkan aturan yang melarang dokumen pelaporan dana BOS diketahui oleh publik khususnya orang tua murid. $^{28}$ Pada dasarnya wali murid bisa melihat seluruh dokumen pencatatan dan pelaporan keuangan sekoolah. Alasannya yaitu Komisi Informasi Pusat telah memutuskan dokumen SPJ dana BOS adalah dokumen terbuka, selama telah diperiksa oleh lembaga pemeriksa dan disampaikan kepada lembaga perwakilan.

Faktor lain yang penyebab terjadinya pungutan pendidikan di SMPN adalah kesibukan wali murid atas pekerjaan pokok. Sehingga wali murid tidak bisa secara penuh memantau kebijakan-kebijakan sekolah, yang berdampak pada keikutsertaan wali murid. Karena wali murid menganggap bahwa kebijakan sekolah tujuannya untuk kebaikan anaknya.

Pola pikir wali murid yang menganggap bahwa dana BOS hanyalah bantuan yang tidak menanggung semua kegiatan yang dilakukan sekolah pada akhirnya dimanfaatkan oleh kepala sekolah untuk melancarkan proses

${ }^{27}$ H.M. Nurul Irfan, Korupsi dalam Hukum Pidana Islam, Amzah, Jakarta, 2011, hlm. 37.

${ }^{28}$ Dhian Prasetyo, Hegemoni Pungutan Pendidikan Pada Wali Murid (Studi Kasus di SMPN 99 Shinobi Konoha Kabupaten Konohagakure), Jurnal Mahasiswa Sosiologi, 2015 jmsos.studentjournal.ub.ac.id, Malang, 2015,th 
pungutan melalui jalur ideologi. Konstruksi pungutan pendidikan yang dilakukan oleh kepala sekolah pada dasarnya dibuat kepala sekolah dan komite sekolah. Selanjutnya agar kebijakan kepala sekolah dan komite sekolah mendapatkan persetujuan maka kepala sekolah dan komite sekolah membuat kebijakan seolah-olah fungsinya kembali kepada wali murid. Sehingga wali murid antusias untuk menyambut kebijakan tersebut. Sehingga pada akhirnya wali murid mau membayar kebijakan pungutan pendidikan. Padahal kebijakan tersebut bertentangan Pasal 9 ayat (1) Permendikbud No 44 Tahun 2012 tentang Pungutan dan Sumbangan Biaya Pendidikan pada Satuan Pendidikan Dasar, yang secara lengkap berbunyi, "satuan pendidikan dasar yang diselenggarakan oleh pemerintah, dan/atau pemerintah daerah dilarang memungut biaya satuan pendidikan". Akan tetapi, meskipun dilarang melakukan pungutan, pihak penyelenggara pendidikan masih bisa mendapatkan pendanaan dengan jalan lain yang bersumber dari orang tua atau wali siswa yakni melalui "sumbangan".

\section{G. Kesimpulan}

1. Kewenangan penyelenggara pendidikan dalam melakukan pungutan pada satuan pendidikan dasar wajib berlandaskan pada hukum positif, agar tindakan atau perbuatan dari pejabatnya tidak bertentangan atau melakukan perbuatan melawan hukum yang mengarah pada penyalahgunaan wewenang dalam melakukan pungutan. Apabila, pihak penyelenggara pendidikan pada satuan pendidikan dasar melakukan pungutan, maka perbuatan tersebut bertentangan dengan Permendikbud No 44 Tahun 2012 tentang Pungutan dan Sumbangan Biaya Pendidikan pada Satuan Pendidikan Dasar. Sehingga, perbuatan tersebut dapat ditindaklanjuti melalui proses penegakan hukum.

2. Terjadinya pungutan liar tentu ada penyebabnya, faktor penyebab pungli secara umum dapat diklasifikasikan menjadi dua macam, yaitu faktor internal dan faktor eksternal. Faktor internal berkaitan dengan pelaku pungli sebagai pemegang amanat berupa jabatan dan wewenang yang diembannya. Sedangkan faktor eksternal berupa sistem pemerintahan dan kepemimpinan serta pengawasan yang tidak seimbang sehingga bisa membuka peluang terjadinya pungli

\section{H. Saran}

1. Bagi penyelenggara pendidikan dalam melaksanakan kewenangannya untuk melakukan tindakan atau perbuatan dalam bentuk apapun harus sesuai dengan peraturan perundang-undangan yang berlaku.

2. Bagi para pengawas sekolah pendidikan dasar, harus lebih efektif lagi dalam mengawasi sekolah binaannya sehingga pungli di sekolah binaannya bisa dicegah sedini mungkin 


\section{DAFTAR PUSTAKA}

\section{A. Buku :}

Amiruddin, Korupsi Dalam Pengadaan Barang dan Jasa, Genta Publishing, Yogyakarta, 2010.

BPKP.Upaya Pencegahan dan Penanggulangan Korupsi pada Pengelolaan Pelayanan Masyarakat, Tim Pengkajian SPKN RI, Jakarta,2002.

Budiyanto, Dasar-Dasar Ilmu Tata Negara, Erlangga, Jakarta, 2000.

H.M. Nurul Irfan, Korupsi dalam Hukum Pidana Islam, Amzah, Jakarta, 2011.

Maria Farida Indrati, Ilmu Perundang-undangan Jenis, Fungsi, dan Materi Muatan. Kanisius, Yogyakarta, 2007.

Philipus M. Hadjon, Penegakan Hukum Adminstrasi, Penerbit Yurika, Jakarta, 2005.

Purwo Djatmiko, Kamus Lengkap Bahasa Indonesia. Anugerah, Surabaya, 2016.

Riduan Syahrabi, Rangkuman Intisari Ilmu Hukum, PT. Citra Aditya Bakti, Bandung.2001

Ridwan HR, Hukum Administrasi Negara. Rajawali Pers, Jakarta,2011.

Saiful anam, Pena Pendidikan, PT. Reka Gagas cipta, Jakarta, 2006.

Satjipto Rahardjo, llmu Hukum, P.T. Citra Aditya Bakti, Bandung, 1991.

Sjachran Basah, Eksistensi dan Tolok Ukur Peradilan Administrasi Negara di Indonesia, Alumni, Bandung, 1997.

Soejono Soekanto, Pokok-Pokok Sosiologi Hukum, Penerbit CV. Rajawali, Jakarta,1986.

\& Sri Mamudji, Penelitian Hukum Normatif: Suatu Tinjauan Singkat, Rajawali Press, Jakarta, 1990 .

Faktor Yang Mempengaruhi Penegakan Hukum, Rajawali Press, Jakarta.2003

Sudikno Metokusumo, Bunga Rampai ilmu Hukum, Penerbit Liberty, Yogyakarta.2003

Theo Huijbers, Filsafat Hukum dalam Lintasan Sejarah, Penerbit Kanisius, Yogyakarta, 2007. 


\section{B. Peraturan Perundang-undangan}

Undang-Undang Dasar Negara Republik Indonesia Tahun 1945.

Undang-Undang Republik Indonesia Nomor 20 tahun 2003 tentang sistem pendidikan nasional

Undang-Undang Nomor 14 Tahun 2005 tentang Guru dan Dosen.

Undang-Undang Nomor 20 tahun 2001 tentang Pemberantasan Tindak Pidana Korupsi

Peraturan Pemerintah Nomor 48 Tahun 2008 tentang Pendanaan Pendidikan

Peraturan Menteri Pendidikan Dan Kebudayaan No 44 tahun 2012 tentang Pungutan Dan Sumbangan Biaya Pendidikan Pada Satuan Dasar

Peraturan Menteri Pendidikan dan Kebudayaan Nomor 75 Tahun 2016 tentang Komite Sekolah

\section{Sumber Lain:}

\section{Jurnal, Skripsi dan Makalah}

Dhian Prasetyo, Hegemoni Pungutan Pendidikan Pada Wali Murid (Studi Kasus di SMPN 99 Shinobi Konoha Kabupaten Konohagakure), Jurnal Mahasiswa Sosiologi, 2015 - jmsos.studentjournal.ub.ac.id, Malang, 2015.

Johan Rahmatulloh, Legalitas Kewenangan Penyelenggara Pendidikan dalam Menarik Pungutan di Satuan Pendidikan Dasar, Jurnal Integritas, Volume 3 Nomor 2 - Desember 2017.

Nabila Zoraya Rahmatullah, Tinjauan Kriminilogis Terhadap Pungutan Liar Oleh Penyelenggara Pendidikan Di Sekolah Yang Berada Di Wilayah Hukum Kota Makassar (Tahun 2011-2013), Skripsi, Program Kekhususan Hukum Pidana Fakultas Hukum Universitas Hasanuddin Makassar 2014.

Muntoha, Pendidikan Dalam Perspektif Hukum (Antara Harapan Dan Realitas), Jurnal Madaniyah, ISSN 2086-3462, Volume 1 Edisi X Januari 2016 .

\section{Internet}

Erna Eprilianti, 2013 Pelaksanaan Pengawasan DPRD Terhadap Kebijakan Perda No. 20 Tahun 2002 Tentang Penyelenggaraan Pendidikan (Studi Deskriptif Pada DPRD Kota Bandung Mengenai Pelanggaran Pungutan 
Liar di sekolah) http:// repository.upi.edu/ 2639/4/S PKN_0906241_Chapter1.pdf, diakses pada tanggal 30/10/2020

Rina Hayati Pengertian Kerangka Berpikir, Jenis, Ciri, dan Cara Menuliskannya, https://penelitianilmiah.com/kerangka-berpikir/ \#: : text=Kerangka\%20berpikir\%20adalah $\% 20$ penjelasan $\% 20$ sementara, argumentasi $\% 20$ kita $\% 20$ dalam $\% 20$ merumuskan $\% 20$ hipotesis. diakses pada tanggal 30/10/2020 